\title{
The role of comorbidities and clinical predictors of severe disease in COVID-19: a systematic review and meta-analysis
}

\author{
Reza Tabrizi ${ }^{1}$, Kamran B Lankarani ${ }^{1}$, Peyman Nowrouzi-sohrabi ${ }^{2}$, Mojtaba Shabani-Borujeni ${ }^{3}$, Shahla \\ Rezaei $^{4}$, Mahnaz Hosseini-bensenjan ${ }^{5}$, Sina vakili ${ }^{2}$, Seyed Taghi Heydari ${ }^{1}$, Mohammad Ali Ashraf $5^{5}$ \\ ${ }^{1}$ Health Policy Research Center, Institute of Health, Shiraz University of Medical Sciences, Shiraz, Iran \\ ${ }^{2}$ Department of Biochemistry, Student Research Committee, Shiraz University of Medical Sciences, \\ Shiraz, Iran \\ ${ }^{3}$ Department of Clinical Pharmacy, Faculty of Pharmacy, Shiraz University of Medical Sciences, Shiraz, \\ Iran \\ ${ }^{4}$ School of Nutrition and Food Sciences, Student Research Committee, Shiraz University of Medical \\ Sciences, Shiraz, Iran
}

${ }^{5}$ Student Research Committee, Shiraz University of Medical Sciences, Shiraz, Iran

Corresponding author*: Mohammad Ali Ashraf

Address: Department of medicine, Building No. 3, School of Medicine, Zand Avenue, Shiraz, Iran.

Tel/ Fax : +98-7132305884

Email: Mohammadali1374.ashraf@gmail.com

\section{Emails:}

\section{Kmsrc89@gmail.com}

peyman.nowroozi2@gmail.com

kblankarani@gmail.com

mojtaba.shabani.brn@gmail.com

shahlarezaei13932014@gmail.com

$\underline{\text { m.hosseyni42@gmail.com }}$

heydari.st@gmail.com

Mohammadali1374.ashraf@gmail.com 


\begin{abstract}
Background

COVID_19 is unpredictable due to non-specific symptoms and clinical course diversity in different individuals. We analyzed studies regarding the factors associated with severe status of the disease to identify unique findings in severely affected patients.
\end{abstract}

\title{
Methods
}

We systematically searched the electronic databases, including PubMed, Scopus, EMBASE, Web of Science, and Google Scholar from inception to $12^{\text {th }}$ of March 2020. Cochrane's Q and I-square statistics were used to assess the existence of heterogeneity between the included studies. We used the randomeffects model to pool the odds ratios (ORs) at $95 \%$ confidence intervals (Cls).

\section{Results}

Seventeen articles out of 3009 citations were included. These contained 3189 patients, of whom 732 were severely affected (severe group) and 3189 were in non-severe group. Using the random-effects model, our meta-analyses showed that the odds of comorbidities, including COPD, DM, HTN, CVD, CKD, and symptoms, including dyspnea, dizziness, anorexia, and cough, were significantly higher among the severe group compared with the non-severe group. There were no significant changes in odds of CVA, liver disease, immunodeficiency/immunosuppression, fever, fatigue, myalgia, headache, diarrhea, sore throat, nasal congestion, sputum, nausea, vomiting, chest pain between the two groups.

\section{Conclusions}

Early recognition and intervention can be critical in management, and might stop progression to severe disease. Predictive symptoms and comorbidities can be used as a predictor in patients who are at risk of severe disease.

Keywords: Comorbidities, clinical determinants, COVID-19, meta-analysis 


\section{Introduction}

Coronaviruses have been responsible for emerging and re-emerging diseases through years, including severe acute respiratory syndrome (SARS) of 2003 and Middle-East respiratory syndrome (MERS) of 2012. ${ }^{1,2}$ Recently, a new coronavirus disease of 2019 (COVID-19) has been identified in Wuhan, China. ${ }^{3}$ Since then, it has spread to 210 countries/territories and infected nearly 2.5 million people around the world. The surge in the number of COVID-19 cases has caused an influx of patients to the hospitals. This has diminished health care resources, including personnel, hospital beds, and intensive care capacities. ${ }^{4}$ Therefore, it is essential to allocate resources for the patients who are at risk of severe disease. ${ }^{5}$

COVID_19 has become unpredictable due to the diversity of the symptoms and severity in different individuals. The clinical spectrum varies from asymptomatic disease to severe pneumonia and multiorgan failure and subsequent death. ${ }^{6}$ Some studies have investigated common clinical symptoms and the role of underlying diseases in the course of the disease. However, there is not a comprehensive opinion in this regard, and available studies are inconclusive. It is essential to gather all available data to provide more reliable information in this regard.

Here, we decided to conduct a comprehensive meta-analysis study to clarify predictive symptoms and the role of comorbidities in severely affected individuals.

\section{Methods}

The Preferred Reporting Items for Systematic Reviews and Meta-analyses (PRISMA) was used in our systematic review and meta-analysis report.

\section{Search Strategy}


medRxiv preprint doi: https://doi.org/10.1101/2020.04.21.20074633; this version posted April 25, 2020. The copyright holder for this preprint (which was not certified by peer review) is the author/funder, who has granted medRxiv a license to display the preprint in perpetuity.

All rights reserved. No reuse allowed without permission.

We systematically searched online databases, including PubMed, Scopus, EMBASE, Web of Science, and Google Scholar from inception to $12^{\text {th }}$ of March 2020. The reference lists of previous reviews and eligible studies were manually checked to find additional studies that did not capture in online searches. The following both medical subject headings (MeSH) and keywords were used in the search strategy: "2019nCoV disease" OR "2019 novel coronavirus disease" OR "COVID-19" OR "COVID19" OR "2019 novel coronavirus infection" OR "coronavirus disease 2019" OR "coronavirus disease-19" OR "2019-nCoV infection" OR "2019-nCoV" OR "2019 novel coronavirus" OR "2019 coronavirus" OR "novel coronavirus" OR (2019 AND coronavirus).

\section{Study selection}

Two researches (M.A-K and N.Z) independently examined the relevant search results according to our inclusion criteria. Any discrepancies among them were resolved through consensus or discussion with a third researcher (RT). Our inclusion criteria included articles that were an original studies (crosssectional, case-control, and cohort design); studies that investigated comorbidities such as chronic obstructive pulmonary disease (COPD), diabetes (DM), hypertension (HTN), cardiovascular disease (CVD), liver disease, chronic kidney disease (CKD), immunodeficiency/immunosuppression, cerebrovascular accident (CVA), symptoms including fever, cough, fatigue, myalgia, headache, diarrhea, sore throat, nasal congestion, sputum production, dyspnea, nausea, vomiting, anorexia, dizziness, chest pain. among others, final outcomes [includes discharge and death] in severe (as measured by disease severity criteria as severe/critical disease type or admitted to ICU or the use of mechanical ventilation) vs. non-severe (patients with mild or non-severe disease type) COVID-19 in English language; studies that reported sufficient data to extract number of intended clinical features for calculating odds ratios (ORs) with $95 \%$ confidence intervals $(95 \% \mathrm{Cl})$ in patients with severe compared with non-severe group. Repeated articles, case reports, case series, literature reviews, letters, editorials, short communication, expert opinions, abstracts without full text, and coronavirus strains other than COVID-19 were excluded. 
medRxiv preprint doi: https://doi.org/10.1101/2020.04.21.20074633; this version posted April 25, 2020. The copyright holder for this preprint

(which was not certified by peer review) is the author/funder, who has granted medRxiv a license to display the preprint in perpetuity.

All rights reserved. No reuse allowed without permission.

\section{Data Extraction and Quality Assessment}

Two independent researchers (N.Z and M.A-K) extracted data from the selected studies for both narrative synthesis and statistical analysis. The following information were extracted: first author's name, year of publication, study type, patient characteristics, study setting, number of investigated comorbidities, symptoms, final outcomes in both severe and non-severe groups. Discrepancies were resolved by consensus or discussion with a third author (P-N.S). To assess the quality of the included articles the Newcastle-Ottawa Scale (NOS) was used. This scale assessed the included studies on three aspects including participant selection, comparability, and exposure/outcome. We considered the quality assessment threshold with a NOS scored $\geq 7$ being defined as good quality.

\section{Statistical Analysis}

Random-effects meta-analysis was selected to estimate the pooled odds ratios (ORs) and its $95 \%$ confidence interval because of the diversity of patient's definitions. Cochrane's $Q$ and I-square statistics were applied to assess heterogeneity across included studies. $I^{2}$ above $70 \%$ and Cochrane's $Q$ test with $P$ $<0.05$ indicated the presence of significant heterogeneity. The potential evidence of publication bias was examined using Egger's regression and Begg's rank correlation tests and also was quantified using Duval \& Tweedie's trim and fill method. Series of sensitivity analyses (with leave-one-out method) were used to evaluate the robustness of our findings after excluding each included study on the pooled ORs of each feature. STATA version 12.0 (Stata Corp., College Station, TX) was used to conduct all statistical analyses.

\section{Results}

As shown in Figure. 1, initial database searches yielded 3009 citations, after removing 1021 duplicate records, 1988 titles and abstracts were screened, and of which 249 full-text articles were retrieved. 
medRxiv preprint doi: https://doi.org/10.1101/2020.04.21.20074633; this version posted April 25, 2020. The copyright holder for this preprint (which was not certified by peer review) is the author/funder, who has granted medRxiv a license to display the preprint in perpetuity.

All rights reserved. No reuse allowed without permission.

Finally, 17 articles met our inclusion criteria. ${ }^{7-23}$ Most of the selected articles were performed in China ${ }^{7-}$

${ }^{22}$, except for one that was conducted in Singapore. ${ }^{23}$ Number of patients in these studies was 3921

persons, of which 732 and 3189 fell in the severe and non-severe groups, respectively. The mean age of the patients in both groups ranged from 37 to 77 years. Most studies clearly stated that clinical data were initial assessments (on admission / before treatment). Table 1 shows an overview of 17 included study characteristics in current systematic review.

\section{Main outcomes}

The pooled OR forest plots of comorbidities and clinical determinants in severe vs. non-severe patients with COVID-19 are illustrated in Appendix 1: 2a-2d.

\section{Comorbidities among severe vs. non-severe patients with COVID-2019}

Using random-effects model, our meta-analyses showed that the odds of comorbidity condition presence such as $\operatorname{CKD}\left(n=6, O R=6.38,95 \% \mathrm{Cl} 3.23-12.59, \mathrm{I}^{2}=0.0 \%\right.$, Q-value $\left.=4.52, P=0.477\right), \operatorname{COPD}(n=$ 8, OR=4.07, 95\% Cl 2.30-7.22, $I^{2}=0.0 \%$, $Q$-value= 3.95, $\left.P=0.786\right), \mathrm{DM}(\mathrm{n}=9, \mathrm{OR}=3.54,95 \% \mathrm{Cl} 1.79-7.01$, $I^{2}=58.4 \%, Q$-value= 19.22, $\left.P=0.014\right), C V D\left(n=9, O R=2.44,95 \% C l\right.$ 1.64-3.63, $I^{2}=0.0 \%, Q$-value= 6.43, $P=$ 0.599), and HTN $\left(n=10, O R=2.35,95 \% \mathrm{Cl} 1.83-3.02, I^{2}=0.0 \%\right.$, $Q$-value $\left.=7.38, P=0.597\right)$ were significantly higher among severe group compared with the non-severe group.

No significant changes in odds of CVA $\left(n=4, O R=3.94,95 \%\right.$ Cl 0.88-17.59, $I^{2}=53.1 \%$, Q-value $=6.40, P=$ 0.094), liver disease $\left(n=6, O R=1.25,95 \% \mathrm{Cl} 0.35-4.41, \mathrm{I}^{2}=40.2 \%, \mathrm{Q}\right.$-value= 8.35, $\left.P=0.138\right)$, immunodeficiency/immunosuppression, $\left(n=3, O R=1.08,95 \% \mathrm{Cl} 0.18-6.26, \mathrm{I}^{2}=0.0 \%, \mathrm{Q}\right.$-value $=0.38, P=$ 0.825) between the two groups were observed (Appendix 1a, Fig: A-H).

Initial symptoms among severe vs. non-severe patients with COVID-2019 
medRxiv preprint doi: https://doi.org/10.1101/2020.04.21.20074633; this version posted April 25, 2020. The copyright holder for this preprint (which was not certified by peer review) is the author/funder, who has granted medRxiv a license to display the preprint in perpetuity.

All rights reserved. No reuse allowed without permission.

Our pooled results on symptoms indicated a significant higher odds of cough ( $n=16, O R=1.42,95 \% \mathrm{Cl}$

$1.11-1.81, I^{2}=23.8 \%$, $Q$-value $\left.=19.68, P=0.185\right)$, dyspnea $\left(n=14, \mathrm{OR}=5.94,95 \% \mathrm{Cl} 3.37-10.45, \mathrm{I}^{2}=\right.$

66.2\%, $Q$-value $=38.42, P<0.001)$, anorexia $\left(n=4, O R=3.18,95 \% C l\right.$ 1.46-6.93, $I^{2}=9.4 \%, Q$-value= 3.31, $P=0.346)$, and dizziness $\left(n=3, O R=4.43,95 \% C l\right.$ 1.69-11.60, $I^{2}=0.0 \%, Q$-value $\left.=0.40, P=0.818\right)$ in the severe group compared with the non-severe group.

But, there were no differences in odds of fever $\left(n=16, \mathrm{OR}=1.20,95 \% \mathrm{Cl} 0.94-1.52, \mathrm{I}^{2}=4.6 \%\right.$, $Q$-value= 15.72, $P=0.401)$, fatigue $\left(n=11, O R=1.49,95 \% C l 0.99-2.24, I^{2}=57.4 \%, Q\right.$-value= 23.49, $\left.P=0.009\right)$, myalgia $\left(n=8, O R=1.21,95 \% \mathrm{Cl} 0.87-1.69, \mathrm{I}^{2}=0.0 \%\right.$, $\mathrm{Q}$-value= 2.69, $\left.\mathrm{P}=0.912\right)$, headache $(\mathrm{n}=9, \mathrm{OR}=1.01$, $95 \% \mathrm{Cl} 0.70-1.46, \mathrm{I}^{2}=0.0 \%$, $\mathrm{Q}$-value $\left.=5.87, \mathrm{P}=0.662\right)$, diarrhea $\left(\mathrm{n}=13, \mathrm{OR}=1.30,95 \% \mathrm{Cl} 0.92-1.84, \mathrm{I}^{2}=\right.$ $0.0 \%$, $Q$-value $=9.54, P=0.656)$, sore throat $\left(n=10, O R=1.22,95 \% C l 0.86-1.75, I^{2}=0.0 \%, Q\right.$-value $=8.50$, $P=0.485)$, nasal congestion $\left(n=4, O R=1.51,95 \% C l 0.32-7.06, I^{2}=46.9 \%\right.$, $Q$-value $\left.=5.65, P=0.130\right)$, sputum production $\left(n=10, O R=1.39,95 \% \mathrm{Cl} 0.89-2.16, \mathrm{I}^{2}=50.7 \%\right.$, $\mathrm{Q}$-value $\left.=18.24, \mathrm{P}=0.032\right)$, nausea $(\mathrm{n}=$ 7, $\mathrm{OR}=1.13,95 \% \mathrm{Cl} 0.58-2.19, \mathrm{I}^{2}=30.9 \%, \mathrm{Q}$-value= 8.69, $\left.\mathrm{P}=0.192\right)$, vomiting $(\mathrm{n}=5, \mathrm{OR}=1.92,95 \% \mathrm{Cl}$ 0.61-6.00, $I^{2}=15.9 \%, Q$-value= 4.76, $\left.P=0.313\right)$, and chest pain $\left(n=5, O R=1.27,95 \% C l 0.44-3.71, I^{2}=\right.$ 14.7\%, Q-value= 4.69, P= 0.321) between the two groups (Appendix 1b, Fig: A-P).

\section{Final outcomes among severe vs. non-severe patients with COVID-2019}

The pooled results indicated that odds of discharge were significantly higher among the non-severe group $\left(n=5, O R=3.05,95 \% \mathrm{Cl} 1.86-5.00, \mathrm{I}^{2}=0.0 \%\right.$, $\mathrm{Q}$-value= 1.90, $\left.\mathrm{P}=0.753\right)$ than the severe group. However, there were a significant increase in the odds of death $\left(n=6, O R=10.56,95 \% \mathrm{Cl} 3.09-36.09, I^{2}=\right.$ $66.6 \%, \mathrm{Q}$-value $=14.95, \mathrm{P}=0.011)$ in the severe group than the non-severe group, as we expected

(Appendix 1d, Fig: A and B).

\section{Sensitivity analyses}


medRxiv preprint doi: https://doi.org/10.1101/2020.04.21.20074633; this version posted April 25, 2020. The copyright holder for this preprint (which was not certified by peer review) is the author/funder, who has granted medRxiv a license to display the preprint in perpetuity.

All rights reserved. No reuse allowed without permission.

We assessed the effect of each study on the robustness of the pooled ORs for each outcome by systematically removing each study from the meta-analyses. The findings of sensitivity analyses showed that there were no significant differences between the pre- and post-sensitivity pooled ORs for COPD, DM, HTN, CVD, liver disease, CKD, immunodeficiency/immunosuppression, fever, headache, chest pain, cough, myalgia, dyspnea, nausea, nasal congestion, discharge, and death. However after omitting Zhang (Jin-jin) et al. ${ }^{7}$, the study on CVA (OR= 6.47, 95\%Cl: $\left.1.10,38.08\right)$, Zhu et al. ${ }^{8}$, the study on sputum

$(\mathrm{OR}=1.58,95 \% \mathrm{Cl}: 1.03,2.41)$, Guan et al. ${ }^{9}$, the study on sore throat $(\mathrm{OR}=1.73,95 \% \mathrm{Cl}: 1.01,2.98)$, Zhu et al. ${ }^{8}$, the study on fatigue $(\mathrm{OR}=1.66,95 \% \mathrm{Cl}: 1.10,2.49)$, Zhang (Jin-jin) et al. ${ }^{7}$, the study on vomiting $(\mathrm{OR}=$ 3.64, 95\% $\mathrm{Cl}: 1.01,13.07)$, Wang et al. ${ }^{10}$, the study on anorexia (OR=1.76, 95\%Cl: $\left.0.52,6.00\right)$, Wang et al. ${ }^{10}$, the study on dizziness (OR=2.92, 95\% Cl: $\left.-0.57,14.88\right)$, Zhang (Jin-jin) et al. ${ }^{7}$, the study on diarrhea (OR=1.49, 95\%Cl: 1.01, 2.18), we found significant differences between pre- and post-sensitivity pooled ORs.

\section{Publication bias}

The Egger's regression and Begg's rank correlation tests were conducted to find publication bias. These indicated no significant publication bias for COPD, HTN, CVD, liver disease, CKD, immunodeficiency/immunosuppression, CVA, fever, cough, myalgia, headache, diarrhea, sore throat, nasal congestion, sputum, nausea, vomiting, dizziness, chest pain, discharge, and death. Because there was evidence of potential publication bias on DM [Egger $(P=0.07)$, Begg $(P<0.01)$ ], dyspnea [Egger $(P=$ 0.02), Begg $(P=0.01)$ ], fatigue [Egger $(p=0.04)$, Begg $(P=0.03)$ ], anorexia [Egger $(p<0.01)$, Begg $(P=$ 0.17)], We applied the non-parametric method (Duval and Tweedie) to estimate the results of censored studies. There were no significant changes between before and after including censored studies for DM, anorexia, dyspnea, and fatigue.

\section{Discussion}


medRxiv preprint doi: https://doi.org/10.1101/2020.04.21.20074633; this version posted April 25, 2020. The copyright holder for this preprint (which was not certified by peer review) is the author/funder, who has granted medRxiv a license to display the preprint in perpetuity.

All rights reserved. No reuse allowed without permission.

We identified comorbidities and initial clinical predictors for severe Covid-19 based on a meta-analysis of 17 studies. Our analysis identified symptoms, including cough, dyspnea, anorexia, and dizziness, and comorbidities, including COPD, DM, HTN, CVD, and CKD, as an indicator of severe disease.

The difference in initial clinical symptoms can be used as an indicator of the severe disease. The odds of dyspnea, dizziness, anorexia, and cough were 5.94, 4.43, 3.18, and 1.42 times, respectively, higher in severe patients than the non-severe group. Two previous meta-analyses reported different results in terms of the predictive symptoms. Jain et al. meta-analysis on seven studies reported dyspnea as the only predictor of severe COVID-19. ${ }^{24}$ However, Gong et al. found cough, fever, and dyspnea as the most clinical manifestation in severe cases..$^{25}$

Guan et al. reported that about $25 \%$ of studied patients had at least one comorbidity. ${ }^{26}$ The impact of comorbidities might be explained by the tissue distribution of the SARS-Cov-2 receptor in host cells. ${ }^{27,28}$ ACE-2 is shown to be host receptor for the binding of SARS-Cov-2 virus to the cell, similar to SARS-CoV. ${ }^{29}$ COPD was higher among severe patients in our study, which is consistent with previous studies. ${ }^{24,26}$ This impact might be due to the higher expression of the ACE-2 receptor among COPD patients. ${ }^{30,31}$ CKD was related to severe disease in our study, as well. Cheng et al. reported higher in-hospital acute kidney injury among patients with abnormal baseline creatinine, which is a determinant of poor prognosis. ${ }^{32}$ Also, there is a higher probability for CKD patients to become critically ill in the course of COVID-19, which might be due to consuming ACE inhibitors and ARBs in this group. Diaz et al. discussed the potential increase of ACE 2 receptors in the patients consuming ACE inhibitors and ARBs, as shown in experimental animals. ${ }^{33}$ DM, HTN, CVD can be a determinant of the severe status of the diseases, in concordance with previous studies as reported by Li et al. ${ }^{34}$ due to the increase in ACE-2 receptors in these populations. ${ }^{35}$

Investigated complications were higher among the severe cases. 
medRxiv preprint doi: https://doi.org/10.1101/2020.04.21.20074633; this version posted April 25, 2020. The copyright holder for this preprint (which was not certified by peer review) is the author/funder, who has granted medRxiv a license to display the preprint in perpetuity.

All rights reserved. No reuse allowed without permission.

The importance of such studies is the early recognition of high risk and critically ill patients. By identifying influential comorbidities on disease severity, we can recognize vulnerable population earlier and provide targeted care.

Comorbidities and predictive symptoms can be applied in clinical practice. Comorbidities can be a good predictor of severe disease. It can be used in recognizing more vulnerable population, and to prevent them from getting the disease by emphasizing protective measures and education.

Predictive symptoms and comorbidities can be used to recognize patients who are at risk of severe disease. Sun et al. mentioned that early and aggressive intervention is an effective way to reduce mortality. ${ }^{36}$ Early recognition and intervention can be critical in management, and might stop progression to severe disease. Therefore, logical allocation of available resources can be very important at this stage.

The present study had some limitations that should be acknowledged. First, definitions of severity across the included studies were inconsistent. However, overall results showed that the odds of death were 10.56 times higher among severe than the non-severe group. This means that the chance of death was significantly higher in the severe group, which implies that patients were in a more critical situation in severe than the non-severe group. second, our analysis was based on small number of studies in some outcomes, however, the relevant results should be interpreted with caution. Third, most of the included studies were from China and may have population biases. Fourth, Heterogeneity across included studies on some outcomes was another limitation and sensitivity analysis was done to address this limitation.

\section{References}

1. Ksiazek TG, Erdman D, Goldsmith CS, Zaki SR, Peret T, Emery S, et al. A Novel Coronavirus Associated with Severe Acute Respiratory Syndrome. New England Journal of Medicine. 2003;348(20):1953-66. 
medRxiv preprint doi: https://doi.org/10.1101/2020.04.21.20074633; this version posted April 25, 2020. The copyright holder for this preprint (which was not certified by peer review) is the author/funder, who has granted medRxiv a license to display the preprint in perpetuity.

All rights reserved. No reuse allowed without permission.

2. Zaki AM, van Boheemen S, Bestebroer TM, Osterhaus AD, Fouchier RA. Isolation of a novel coronavirus from a man with pneumonia in Saudi Arabia. The New England journal of medicine. 2012;367(19):1814-20.

3. Zhu N, Zhang D, Wang W, Li X, Yang B, Song J, et al. A Novel Coronavirus from Patients with Pneumonia in China, 2019. New England Journal of Medicine. 2020;382(8):727-33.

4. Remuzzi A, Remuzzi G. COVID-19 and Italy: what next? The Lancet. 2020;395(10231):1225-8.

5. Emanuel EJ, Persad G, Upshur R, Thome B, Parker M, Glickman A, et al. Fair Allocation of Scarce Medical Resources in the Time of Covid-19. New England Journal of Medicine. 2020.

6. Xu Z, Li S, Tian S, Li H, Kong L-Q. Full spectrum of COVID-19 severity still being depicted. Lancet. 2020;395(10228):947-8.

7. Zhang J-j, Dong X, Cao Y-y, Yuan Y-d, Yang Y-b, Yan Y-q, et al. Clinical characteristics of 140 patients infected with SARS-CoV-2 in Wuhan, China.n/a(n/a).

8. Zhu X, Yuan W, Huang K, Wang Q, Yao S, Lu W, et al. Clinical Features and Short-Term Outcomes of 114 Elderly Patients with COVID-19 in Wuhan, China: A Single-Center, Retrospective, Observational Study. 2020.

9. Guan W-j, Ni Z-y, Hu Y, Liang W-h, Ou C-q, He J-x, et al. Clinical Characteristics of Coronavirus Disease 2019 in China. New England Journal of Medicine. 2020.

10. Wang D, Hu B, Hu C, Zhu F, Liu X, Zhang J, et al. Clinical Characteristics of 138 Hospitalized Patients With 2019 Novel Coronavirus-Infected Pneumonia in Wuhan, China. JAMA. 2020;323(11):1061-9.

11. Cai Q, Huang D, Ou P, Yu H, Zhu Z, Xia Z, et al. 2019-nCoV Pneumonia in a Normal Work Infectious Diseases Hospital Besides Hubei Province, China. 2020.

12. Cao W. Clinical features and laboratory inspection of novel coronavirus pneumonia (COVID-19) in Xiangyang, Hubei. medRxiv. 2020:2020.02.23.20026963. 
medRxiv preprint doi: https://doi.org/10.1101/2020.04.21.20074633; this version posted April 25, 2020. The copyright holder for this preprint (which was not certified by peer review) is the author/funder, who has granted medRxiv a license to display the preprint in perpetuity.

All rights reserved. No reuse allowed without permission.

13. Huang C, Wang Y, Li X, Ren L, Zhao J, Hu Y, et al. Clinical features of patients infected with 2019 novel coronavirus in Wuhan, China. 2020;395(10223):497-506.

14. Jian-ya GJM. Clinical characteristics of 51 patients discharged from hospital with COVID-19 in Chongqing, China. 2020.

15. Li K, Wu J, Wu F, Guo D, Chen L, Fang Z, et al. The Clinical and Chest CT Features Associated with Severe and Critical COVID-19 Pneumonia. Invest Radiol. 2020.

16. Liu J, Liu Y, Xiang P, Pu L, Xiong H, Li C, et al. Neutrophil-to-Lymphocyte Ratio Predicts Severe Illness Patients with 2019 Novel Coronavirus in the Early Stage. medRxiv.

2020:2020.02.10.20021584.

17. Liu S, Luo H, Wang Y, Wang D, Ju S, Yang YJC. Characteristics and Associations with Severity in COVID-19 Patients: A Multicentre Cohort Study from Jiangsu Province, China. 2020.

18. Liu W, Wang F, Li G, Wei Y, Li X, He L, et al. Analysis of 2019-nCoV Infection and Clinical Manifestations of Outpatients: An Epidemiological Study from the Fever Clinic in Wuhan, China. 2020.

19. Liu Y, Sun W, Li J, Chen L, Wang Y, Zhang L, et al. Clinical features and progression of acute respiratory distress syndrome in coronavirus disease 2019. medRxiv; 2020.

20. Tian S, Hu N, Lou J, Chen K, Kang X, Xiang Z, et al. Characteristics of COVID-19 infection in Beijing. Journal of Infection. 2020;80(4):401-6.

21. Xu Y-H, Dong J-H, An W-M, Lv X-Y, Yin X-P, Zhang J-Z, et al. Clinical and computed tomographic imaging features of novel coronavirus pneumonia caused by SARS-CoV-2. Journal of Infection. 2020;80(4):394-400.

22. Zhang F, He L, Ouyang Y, Gong J, Li X, Wei Y, et al. Clinical Features of 81 Hospitalized Patients with 2019 Novel Coronavirus-Infected Pneumonia in Jingzhou, China: A Descriptive Study. 2020. 
medRxiv preprint doi: https://doi.org/10.1101/2020.04.21.20074633; this version posted April 25, 2020. The copyright holder for this preprint (which was not certified by peer review) is the author/funder, who has granted medRxiv a license to display the preprint in perpetuity.

All rights reserved. No reuse allowed without permission.

23. Young BE, Ong SWX, Kalimuddin S, Low JG, Tan SY, Loh J, et al. Epidemiologic Features and Clinical Course of Patients Infected With SARS-CoV-2 in Singapore. JAMA. 2020.

24. Jain V, Yuan J-M. Systematic review and meta-analysis of predictive symptoms and comorbidities for severe COVID-19 infection. medRxiv. 2020:2020.03.15.20035360.

25. Gong Z-j, Zhang H-y, Jiao F-z, Wu X-j, Shang M, Luo Y-c. Clinical features, treatments and outcomes of severe and critical severe patients infected with COVID-19: A system review and meta-analysis. Research Square; 2020.

26. Guan W-j, Liang W-h, Zhao Y, Liang H-r, Chen Z-s, Li Y-m, et al. Comorbidity and its impact on 1590 patients with Covid-19 in China: A Nationwide Analysis. 2020.

27. Song R, Preston G, Yosypiv I. Ontogeny of angiotensin-converting enzyme 2. Pediatric Research 2011; 71: 13-19.

28. Xu H, Zhong L, Deng J et al. High expression of ACE2 receptor of 2019-nCoV on the epithelial cells of oral mucosa. International Journal of Oral Science 2020; 12. DOI:10.1038/s41368-0200074-x.

29. Tai W, He L, Zhang X et al. Characterization of the receptor-binding domain (RBD) of 2019 novel coronavirus: implication for development of RBD protein as a viral attachment inhibitor and vaccine. Cellular \& Molecular Immunology 2020. DOI:10.1038/s41423-020-0400-4.

30. Brake SJ, Barnsley K, Lu W, McAlinden KD, Eapen MS, Sohal SS. Smoking upregulates angiotensin-converting enzyme-2 receptor: a potential adhesion site for novel coronavirus SARSCoV-2 (Covid-19). Multidisciplinary Digital Publishing Institute; 2020.

31. Lippi G, Henry BMJRM. Chronic obstructive pulmonary disease is associated with severe coronavirus disease 2019 (COVID-19). 2020.

32. Cheng $Y$, Luo R, Wang K, Zhang M, Wang Z, Dong L, et al. Kidney disease is associated with inhospital death of patients with COVID-19. 2020. 
medRxiv preprint doi: https://doi.org/10.1101/2020.04.21.20074633; this version posted April 25, 2020. The copyright holder for this preprint (which was not certified by peer review) is the author/funder, who has granted medRxiv a license to display the preprint in perpetuity. All rights reserved. No reuse allowed without permission.

33. Diaz JHJJoTM. Hypothesis: angiotensin-converting enzyme inhibitors and angiotensin receptor blockers may increase the risk of severe COVID-19. 2020.

34. Li B, Yang J, Zhao F, Zhi L, Wang X, Liu L, et al. Prevalence and impact of cardiovascular metabolic diseases on COVID-19 in China. 2020:1-8.

35. Fang L, Karakiulakis G, Roth MJTLRM. Are patients with hypertension and diabetes mellitus at increased risk for COVID-19 infection? 2020.

36. Sun Q, Qiu H, Huang M, Yang YJAolC. Lower mortality of COVID-19 by early recognition and intervention: experience from Jiangsu Province. 2020;10(1):1-4. 
Table 1. Characteristics of included studies

\begin{tabular}{|c|c|c|c|c|c|c|c|c|}
\hline Authors & $\begin{array}{c}\text { Publication } \\
\text { year }\end{array}$ & country & $\begin{array}{c}\text { Sample size } \\
\text { (Severe/non- } \\
\text { severe) }\end{array}$ & Study design" & $\begin{array}{c}\text { Patients (Severe/Non- } \\
\text { sever) }\end{array}$ & $\begin{array}{l}\text { Age group } \\
\text { (Severe vs } \\
\text { Non-Severe) }\end{array}$ & $\begin{array}{c}\text { Quality } \\
\text { assessment } \\
\text { (score) }\end{array}$ & Reference \\
\hline Cai et al,. & 2020 & China & $58 / 240$ & Cross-sectional & Severe/non-severe & $\begin{array}{l}64 \pm 7.41 \\
40 \pm 18.53\end{array}$ & 8 & 11 \\
\hline Cao (Weiliang) et al,. & 2020 & China & $21 / 107$ & Case-control (retrospective) & Severe/non-severe & NR & 4 & 12 \\
\hline Guan et al,. & 2020 & China & $173 / 926$ & (Cohort) & Severe/ non-severe & $\begin{array}{l}52 \pm 18.53 \\
45 \pm 17.05\end{array}$ & 6 & 9 \\
\hline Huang et al,. & 2020 & China & $13 / 28$ & (Cohort) & ICU care/ non-ICU care & $\begin{array}{c}49 \pm 14.83 \\
49 \pm 12.23\end{array}$ & 5 & 13 \\
\hline Jian-ya et al,. & 2020 & China & $7 / 44$ & $\begin{array}{l}\text { Retrospective, single-center } \\
\text { case series (case-control) }\end{array}$ & Severe/ non-severe & $\begin{array}{l}52 \pm 11.86 \\
44 \pm 11.86\end{array}$ & 3 & 14 \\
\hline Li et al,. & 2020 & China & $25 / 58$ & Retrospective (case-control) & $\begin{array}{l}\text { Severe or } \\
\text { critical/ordinary }\end{array}$ & $\begin{array}{l}53.7 \pm 12.3 \\
41.9 \pm 10.6\end{array}$ & 5 & 15 \\
\hline Liu (Jingyuan) et al,. & 2020 & China & $17 / 44$ & $\begin{array}{l}\text { Prospective single-center } \\
\text { (case-control) }\end{array}$ & $\begin{array}{l}\text { Severe or critical/ } \\
\text { commo type }\end{array}$ & $\begin{array}{l}56 \pm 9.75 \\
41 \pm 18.75\end{array}$ & 5 & 16 \\
\hline Liu (Songqiao) et al,. & 2020 & China & $53 / 567$ & $\begin{array}{c}\text { Retrospective multicentre } \\
\text { cohort }\end{array}$ & $\begin{array}{l}\text { Severe or critical/ } \\
\text { asymptomatic or mild or } \\
\text { moderate }\end{array}$ & $44.48 \pm 17.16$ & 9 & 17 \\
\hline Liu (Wenhua) et al,. & 2020 & China & $75 / 553$ & $\begin{array}{l}\text { Retrospective single center } \\
\text { case series (case-control) }\end{array}$ & Severe or critical/mild & $\begin{array}{l}57 \pm 11.5 \\
52 \pm 15.1\end{array}$ & 5 & 18 \\
\hline Liu (Yanli) et al,. & 2020 & China & $53 / 56$ & Retrospective (cohort) & ARDS/non-ARDS & $\begin{array}{c}61 \pm 13.34 \\
49 \pm 16.31 \\
\end{array}$ & 8 & 19 \\
\hline Tian et al,. & 2020 & China & $46 / 216$ & Retrospective (case-control) & Severe/common & $\begin{array}{l}61.4 \pm 23.25 \\
\quad 44.5 \pm 23\end{array}$ & 5 & 20 \\
\hline Wang et al,. & 2020 & China & $36 / 102$ & $\begin{array}{l}\text { Retrospective, single-center } \\
\text { case series (cohort) }\end{array}$ & ICU/non-ICU & $\begin{array}{r}66 \pm 15.57 \\
51 \pm 18.53 \\
\end{array}$ & 7 & 10 \\
\hline Xu et al,. & 2020 & China & $13 / 37$ & Retrospective (case-control) & $\begin{array}{l}\text { Severe or critical/ mild } \\
\text { or moderate }\end{array}$ & NR & 5 & 21 \\
\hline Young et al,. & 2020 & Singapore & $6 / 12$ & $\begin{array}{l}\text { Descriptive case series } \\
\text { (cohort) }\end{array}$ & $\begin{array}{l}\text { Required supplemental } \\
\text { O2/ not required } \\
\text { supplemental O2 }\end{array}$ & $\begin{array}{l}56 \pm 6.5 \\
37 \pm 6.25\end{array}$ & 6 & 23 \\
\hline
\end{tabular}




\begin{tabular}{|l|c|c|c|c|c|c|c|}
\hline Zhang (Fengqin) et al,. & 2020 & China & $35 / 46$ & $\begin{array}{c}\text { Retrospective single center } \\
\text { (case-control) }\end{array}$ & $\begin{array}{l}\text { Severe or } \\
\text { critical/common }\end{array}$ & $44 \cdot 47 \pm 13 \cdot 3$ \\
\hline Zhang (Jin-jin) et al,. & 2020 & China & $58 / 82$ & (Cross-sectional) & Severe/non-severe & $\begin{array}{c}64 \pm 15.5, \\
51.5 \pm 13\end{array}$ & 6 \\
\hline Zhu et al,. & 2020 & China & $43 / 71$ & Retrospective (cohort) & severe/non-severe & $76 \pm 6.67$, \\
$77 \pm 8.15$
\end{tabular}




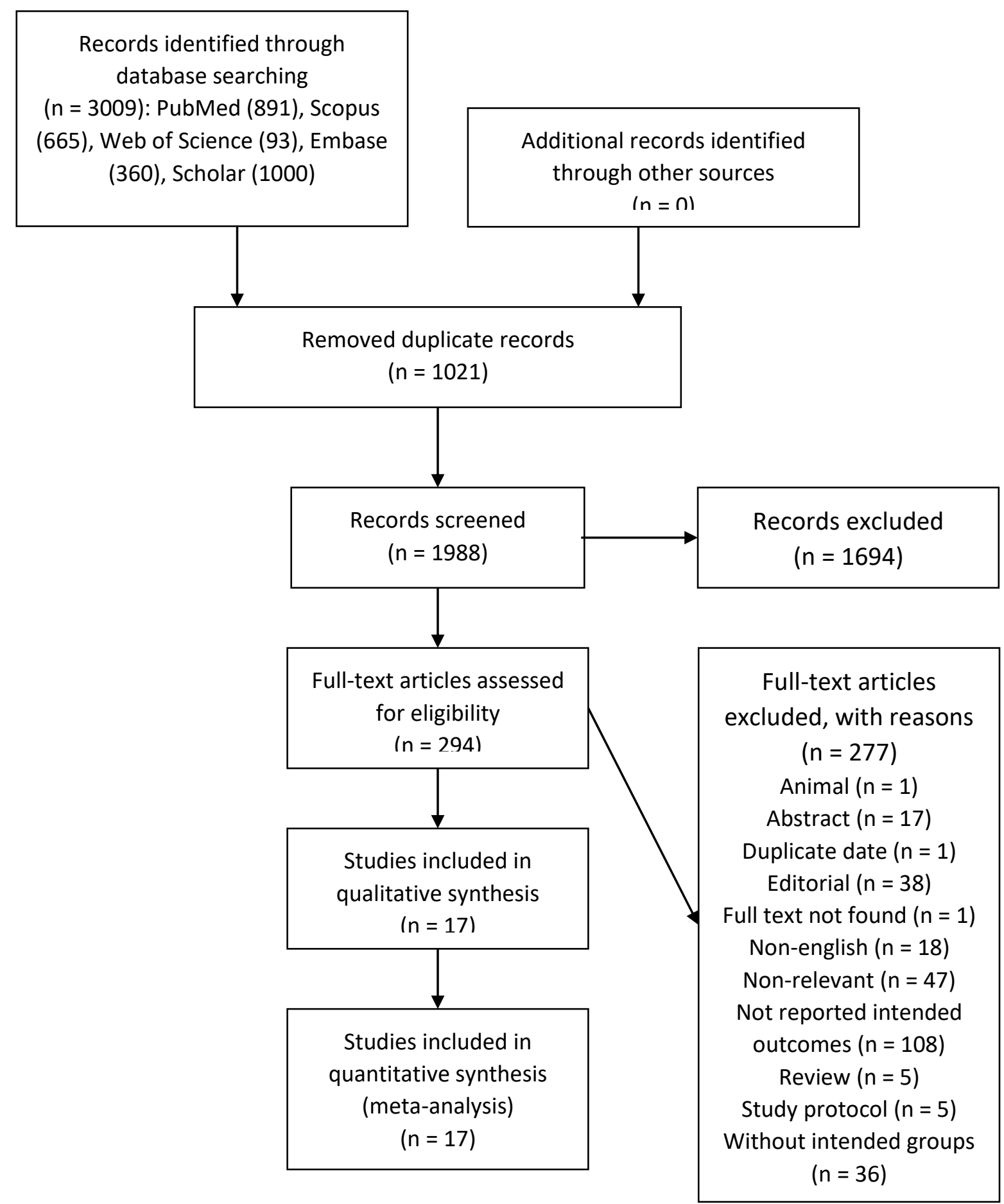

Figure. 1. Study identificantion and selection process. 